\title{
A complex intervention to improve intercultural communication and Aboriginal patient outcomes: which components worked?
}

\author{
Anna P Ralph ( $\sim$ anna.ralph@menzies.edu.au ) \\ https://orcid.org/0000-0002-2253-5749 \\ Vicki Kerrigan \\ Menzies School of Health Research, Charles Darwin University \\ Craig Castillon \\ Top End Health Service
}

Vincent Mithen

Menzies School of Health Research, Charles Darwin University https://orcid.org/0000-0002-0634-6913

Elise O'Connor

Top End Health Service

Martin Hansen

Top End Health Service

Natasha Keilor

Top End Health Service

Robyn Aitken

Flinders University

Gail Madrill

Top End Health Service

Curtis Roman

NT Aboriginal Interpreter Service

Alan Cass

Menzies School of Health Research, Charles Darwin University

Short report

Keywords: Aboriginal, communication, cultural safety, interpreter

Posted Date: August 17th, 2020

DOI: https://doi.org/10.21203/rs.3.rs-57912/v1 
License: (c) (i) This work is licensed under a Creative Commons Attribution 4.0 International License. Read Full License 


\section{Abstract \\ Background}

Aboriginal language interpreters are under-utilised in healthcare in northern Australia. Self-discharge from hospital is an adverse outcome occurring at high rates among Aboriginal people, with poor communication thought to be a contributor. We previously reported increased Aboriginal interpreter uptake and decreased rates of self-discharge during implementation of a 12-month hospital-based intervention. Interrupted time-series analysis showed sudden increase and up-trending improvement in interpreter use, and a corresponding decrease in self-discharge rates, during a 12-month intervention period (April 2018 - March 2019) compared with a 24-month baseline period (April 2016 - March 2018). This paper aims to explore reasons for these outcomes, and further explore the likelihood of a causal association between study activities and outcomes.

\section{Methods}

We used the 'Template for Intervention Description and Replication' (TIDieR) as a framework to describe intervention components and evaluate their relative importance. Information on intercurrent activities that may have contaminated study findings was reviewed. The relationship between proportion of hospital separations among Aboriginal people ending in self-discharge and numbers of Aboriginal interpreter bookings made during April 2016-March 2019 was tested using linear regression.

\section{Results}

One full-time Aboriginal Interpreter Coordinator was employed for the intervention period who identified language needs, promoted interpreter use and mentored interpreters. The intervention period start date corresponded with commencement of this role. Three 'Working with Interpreter' training sessions were held during the intervention period reaching 83 clinicians, and three medical officers volunteered as champions of interpreter use in hospital practice. Employment of the Aboriginal Interpreter Coordinator was deemed the most important component of the intervention, based on reach compared to the other components and timing of the changes in outcomes. There was an inverse association between interpreter bookings and self-discharge rate among Aboriginal inpatients $(p=0.02)$. This association, the timing of changes and assessment of intercurrent activities at the hospital indicated that the study intervention was likely to be casually related to the measured outcomes.

\section{Conclusions}

Communication in healthcare can be improved through targeted strategies, with associated improvements in patient outcomes. Health services with high interpreter needs would benefit from 


\section{Contributions To The Literature}

- Bundled interventions are used widely in healthcare to improve patient care. Disentangling the relative contributions of intervention components can be challenging.

- After finding positive outcomes from an intervention to improve communication between healthcare providers and Australian Aboriginal patients, we used the 'Template for Intervention Description and Replication' to assesses of the contribution of each component. The components were: employment of an Aboriginal Interpreter Coordinator, working with interpreter training for doctors, and championing interpreter use.

- Employment of the Coordinator appeared most important in increasing interpreter uptake, but the bundled activities may have been synergistic in supporting behaviour change among healthcare providers.

\section{Introduction}

Effective communication between Aboriginal language-speaking patients and healthcare providers requires cultural respect and appropriate interpreter use. Use of professional interpreters can improve patient outcomes[1, 2] but in Australia's Northern Territory (NT), where dozens of languages are commonly spoken [3], uptake of interpreters is low for people who primarily speak an Aboriginal language[4]. Poor communication compounds existing health disparities. Adverse outcomes for Aboriginal patients including death have been attributed to communication failures [5-7]. One outcome considered a consequence of impaired communication is the high rate of self-discharge from NT hospitals, with resulting health costs to individuals, negative impacts on staff morale, and high health system costs[8-10].

Previously we found that healthcare providers at the largest tertiary NT hospital lack skills in identifying language need or working with interpreters, face a convoluted bookings process and may experience frustration due to interpreter unavailability [4].

In response, Top End Health Services which manages Royal Darwin Hospital, supported the employment of an Aboriginal Interpreter Coordinator for a 12-month pilot period. The study team supplemented this with additional activities to provide a 'bundle' of interventions: training sessions for healthcare providers about working effectively with Aboriginal interpreters, and clinical championing of interpreter use, whereby volunteer medical officers promoted interpreter use in the hospital. The concept of 'care bundles' is common in hospital practice to improve quality of care.[11] We conducted a quasi-experimental pilot study using interrupted time-series analysis to determine effects of the intervention on interpreter bookings made (primary outcome measure), bookings completed and self-discharge rates by Aboriginal people (secondary outcomes), during a 24-month baseline period (April 2016 - March 2018) and a 12month intervention period (April 2018 - March 2019), and found that study activities were associated with 
immediate and up-trending increases in Aboriginal interpreter bookings, and a downtrend in selfdischarges.[12]

The aims of this paper are to explore the likely reasons for the improved interpreter uptake identified during the study period; specifically to determine which components of the intervention should best be invested in by the health service, and other health services into the future, to sustain change. Further, we wished to explore the likelihood of a causal association between study activities and the decrease in selfdischarge rates which occurred during the study intervention period.

\section{Methods}

\section{Design}

This is an evaluation of a complex intervention[13] using the Template for Intervention Description and Replication (TIDieR) as a framework[14]. Each intervention component is described in the template according to what it comprised, who implemented it, how, where, when and how much, whether modifications were made during the study and reach of each component (how well it was implemented).

Main findings are published elsewhere.[12] In brief, the primary outcome, which measured healthcare provider behaviour, was the proportion of Aboriginal patients needing an interpreter for whom an interpreter booking was made in the intervention period (1 April 2018-31 March 2019) compared with the baseline period (1 April 2016-31 March 2018). Secondary outcomes were: proportion of Aboriginal interpreter bookings completed in the intervention compared with baseline period and proportion of Aboriginal admissions ending in self-discharge during the two periods. The study was conducted as part of a collaborative initiative called the 'Communicate Study' between Menzies School of Health Research, Royal Darwin Hospital and the NT Aboriginal Interpreter Service.

A 'cultural safety' lens underpinned delivery and evaluation. Cultural safety requires organizations and individuals to critique existing power structures and review the policies, procedures, and practices which maintain health inequity [16]. A monitoring framework has been proposed by the Australian Institute of Health and Welfare to guide assessments of 'Cultural safety in healthcare for Indigenous Australians' [18].The study responded to this framework by addressing how health care services are provided (whether Aboriginal interpreters are used) and Indigenous patients' experience of health care (reflected in selfdischarge rate). Additionally, implementation and delivery included Aboriginal leadership. Note, the term 'Indigenous' refers collectively to Aboriginal and Torres Strait Islander peoples. Our study focused on Aboriginal patients, who form the large majority of Indigenous patients at the study setting.

\section{Setting}

Royal Darwin Hospital is a 360-bed tertiary centre in the NT. Around 100 Aboriginal languages and dialects are spoken in the NT [3]. Prior estimates indicate approximately $60 \%$ of Aboriginal people at Royal Darwin Hospital [4] and in the NT [19] speak an Aboriginal language as their first language. 
Community consultation indicates that the majority would benefit from an interpreter in healthcare interactions [20]. We conservatively estimated that $50 \%$ of Aboriginal patient separations would benefit from an interpreter. Royal Darwin Hospital uses the offsite Aboriginal Interpreter Service which services a number of government agencies. Interpreters are available for face-to-face, telephone or audio-visual interpreting. The service also provides one 'rostered interpreter' to the hospital on weekdays for four hours.

\section{Data}

All Aboriginal interpreter bookings data for 1 April 2016-31 March 2019 were provided by the NT Aboriginal Interpreter Service including ward, language and whether completed or cancelled. Royal Darwin Hospital separations data (discharged or transferred, left against medical advice/discharge at own risk, died, unknown, other or change of care type) were used as a count of admissions. Data were obtained for all Indigenous people for the same timeframe.. In this paper we use 'self-discharge' synonymously with 'left against medical advice/discharge at own risk'.. Torres Strait Islanders, admissions for dialysis, same-day procedures, private hospital, outpatient cardiology, borders and care provided in psychiatry units (where interpreter use is already high)[4] were excluded.

\section{Evaluation and analyses}

The TIDieR framework was populated for each study intervention component: employment of an Aboriginal Interpreter Coordinator, 'Working with Interpreter' training, and championing of interpreter use. Timing of activities was compared to the interrupted time-series analysis plots of interpreter bookings and self-discharge rates.[12] Other activities underway at the hospital independent of this study that may have impacted study outcomes were ascertained and documented through discussions with other clinicians and researchers and members of the health services executive. Health service data custodians and analysts were consulted to determine whether capture of hospital separations data had changed during the period 2016-2019. Quantitative analysis was undertaken using Stata version 15.1.[21] Simple linear regression was used to examine the relationship between numbers of interpreter bookings made per month and self-discharge rates.

\section{Ethics}

Approval was provided by the Ethics Committee of the Northern Territory Department of Health and Menzies School of Health Research (HREC-2017-3007 and HREC-2018-3245).

\section{Results}

\section{Original study findings}

As previously reported, interpreter booking requests increased - especially telephone or AV interpreting and admissions ending in self-discharge decreased in the intervention compared with baseline periods (Table 1).[12] Self-discharge as a proportion of all discharges (using predicted values from the regression 
model) fell from 12.0\% in April 2018 to $10.1 \%$ in March 2019. The most common language requests were for Yolngu Matha, Murrinh-Patha and Kunwinjku. 
Table 1

Royal Darwin Hospital separations (Aboriginal people) and interpreter booking requests during the baseline and intervention periods

\begin{tabular}{|c|c|c|}
\hline & $\begin{array}{l}\text { 2-year baseline } \\
\text { period }\end{array}$ & $\begin{array}{l}\text { 1-year intervention } \\
\text { period }\end{array}$ \\
\hline All admissions & 21163 & 10919 \\
\hline Aboriginal interpreter bookings made & 1333 & 958 \\
\hline Aboriginal interpreter bookings completed & 761 & 607 \\
\hline $\begin{array}{l}\text { Number of people estimated to need an Aboriginal } \\
\text { interpreter }\end{array}$ & 10582 & 5460 \\
\hline $\begin{array}{l}\text { Proportion in need for whom interpreter booking } \\
\text { made* }\end{array}$ & $12.6 \%$ & $17.5 \%$ \\
\hline $\begin{array}{l}\text { Proportion in need for whom interpreter booking } \\
\text { completed* }\end{array}$ & $7.2 \%$ & $11.1 \%$ \\
\hline \multicolumn{3}{|l|}{ Languages requested } \\
\hline Yolngu Matha & $478(35.9 \%)$ & $315(32.9 \%)$ \\
\hline Murrinh-Patha & $244(18.3 \%)$ & $158(16.5 \%)$ \\
\hline Kunwinjku & $126(9.5 \%)$ & $116(12.1 \%)$ \\
\hline Kriol & $105(7.9 \%)$ & $79(8.2 \%)$ \\
\hline Tiwi & $100(7.5 \%)$ & $76(7.9 \%)$ \\
\hline Anindilyakwa & $65(4.9 \%)$ & $67(7.0 \%)$ \\
\hline Burarra & $69(5.2 \%)$ & $43(4.5 \%)$ \\
\hline Warlpiri & $50(3.8 \%)$ & $35(3.7 \%)$ \\
\hline Other languages & $96(7.2 \%)$ & $69(7.2 \%)$ \\
\hline \multicolumn{3}{|l|}{ Location } \\
\hline Inpatient ward & $870(65.3 \%)$ & $467(48.7 \%)$ \\
\hline Telephone interpreter or audio-visual link** & 370 (27.8\%) & 405 (42.3\%) \\
\hline Emergency Department & $26(2.0 \%)$ & $29(3.0 \%)$ \\
\hline
\end{tabular}

\section{Legend:}

*The proportion of Aboriginal patients estimated to benefit from an interpreter was set at $50 \%$ of hospital separations for Aboriginal people, where Aboriginal people were those coded as 'Aboriginal' or 'Aboriginal and Torres Strait Islander'. 'Torres Strait Islander and not Aboriginal' were excluded.

*thospital location for telephone and audio-visual interpreting not provided 


\begin{tabular}{|lll|}
\hline & $\begin{array}{l}\text { 2-year baseline } \\
\text { period }\end{array}$ & $\begin{array}{l}\text { 1-year intervention } \\
\text { period }\end{array}$ \\
\hline $\begin{array}{l}\text { Intensive Care, High Dependency, } \\
\text { Neonatal Intensive Care }\end{array}$ & $25(1.9 \%)$ & $26(2.7 \%)$ \\
\hline Coronary Care Unit & $30(2.3 \%)$ & $22(2.3 \%)$ \\
\hline Other locations & $12(0.9 \%)$ & $9(0.9 \%)$ \\
\hline $\begin{array}{l}\text { Legend: } \\
\text { *The proportion of Aboriginal patients estimated to benefit from an interpreter was set at 50\% of } \\
\text { hospital separations for Aboriginal people, where Aboriginal people were those coded as 'Aboriginal' } \\
\text { or 'Aboriginal and Torres Strait Islander'. 'Torres Strait Islander and not Aboriginal' were excluded. }\end{array}$ \\
\hline **hospital location for telephone and audio-visual interpreting not provided \\
\hline
\end{tabular}

\section{Evaluation of intervention components using the TIDieR framework}

The study intervention period commencement date was chosen to coincide with the date of commencement of the Aboriginal Interpreter Coordinator. The Coordinator had training and experience as an Aboriginal Health Practitioner and Aboriginal Liaison Officer and was familiar with the health service (Table 2). While the role was conceived as being a coordinator role to improve efficiency and ease of bookings, it was in fact realised somewhat differently, focussing more on Aboriginal staff support, particularly provision of mentoring for interpreters on assignment to the hospital. It became apparent that the complexity of the hospital - the physical structure and processes and procedures - can be daunting to Aboriginal interpreter staff, such that a support role helping them to navigate the complex environment was greatly valued. 
Table 2

Description of study intervention activities according to the Template for Intervention Description and Replication (TIDieR) checklist

\begin{tabular}{|ll|l|}
\hline Item & Description \\
\hline Why & $\begin{array}{l}\text { The Communicate Study: A health systems intervention to improve uptake of Aboriginal } \\
\text { interpreters at a tertiary referral hospital. }\end{array}$ \\
\hline & $\begin{array}{l}\text { An estimated } 50 \% \text { of hospital separations of Aboriginal people at Royal Darwin Hospital } \\
\text { are for Aboriginal language speakers who would benefit from the use of an interpreter, } \\
\text { but few get access. Ineffective communication about health matters including diagnosis, } \\
\text { treatment and prognosis is associated with poor health outcomes, while interpreter use } \\
\text { can improve outcomes. Systems changes are needed to support greater uptake of } \\
\text { interpreters. High quality inter-cultural communication is one component of culturally } \\
\text { safe care. }\end{array}$ & $\begin{array}{l}\text { Clinical } \\
\text { championing of } \\
\text { interpreter use }\end{array}$ \\
What & $\begin{array}{l}\text { Employment of a } \\
\text { hospital-based } \\
\text { Aboriginal Interpreter }\end{array}$ & Working with Interpreter' training \\
Coordinator & sessions: &
\end{tabular}


Item Description

An Aboriginal

Interpreter

Coordinator was

employed to address

barriers to interpreter

use. The individual

appointed to the role

remained in the role

for the whole study

period with no staff

turnover. They had

prior training as an

Aboriginal Health

Practitioner and work

experience as an

Aboriginal Liaison

Officer. Aims of the

role as originally

conceived were to:

- Provide a central

point of contact for

health care providers

to make bookings.

- Coordinate the efficient use of on-site interpreters (i.e. pro-

actively seeking

clients who need a

same-language

interpreter and

informing the medical

team that they are on site).

- Ensure the rostered interpreter is used effectively.
These comprised 60 minute hospitalbased training sessions provided by the Aboriginal Interpreter Service for all new interns during their orientation days, and for doctors in specific divisions (Emergency department; Surgical division), addressing: an introduction to how different languages work; overview of Aboriginal languages spoken in the Northern Territory; why context is important in communication; how to avoid common areas of miscommunication; how to communicate in plain English; how to work with an interpreter effectively; practical tips for booking and using Aboriginal interpreters.
Medical officers working in the hospital volunteered as 'clinical champions', ensuring use of interpreters in their clinical role and advocating use to colleagues. 'Champions' met regularly with the study team to discuss barriers and facilitators, and ways to advocate for and promote the use of interpreters in their daily work. 


\begin{tabular}{|c|c|c|c|}
\hline Item & Description & & \\
\hline Materials & $\begin{array}{l}\text { The Aboriginal } \\
\text { Interpreter } \\
\text { Coordinator was } \\
\text { introduced at a } \\
\text { Hospital Grand } \\
\text { Rounds session, was } \\
\text { a visible presence on } \\
\text { wards, and sent } \\
\text { regular emails to all } \\
\text { clinical staff relating } \\
\text { to Aboriginal } \\
\text { interpreter matters, } \\
\text { such as whether there } \\
\text { was a rostered } \\
\text { interpreter onsite and } \\
\text { what language(s) } \\
\text { they spoke. }\end{array}$ & $\begin{array}{l}\text { Training materials included documents } \\
\text { containing contact details for the } \\
\text { Interpreter Service and showing } \\
\text { language names mapped to Aboriginal } \\
\text { communities and districts of the } \\
\text { Northern Territory. }\end{array}$ & $\begin{array}{l}\text { Champions helped } \\
\text { to make sure } \\
\text { posters and fliers } \\
\text { about the NT } \\
\text { Aboriginal } \\
\text { Interpreter Service } \\
\text { were visible on } \\
\text { hospital } \\
\text { noticeboards, and } \\
\text { to place bookings } \\
\text { forms in prominent } \\
\text { places on the } \\
\text { different wards. }\end{array}$ \\
\hline $\begin{array}{l}\text { Who } \\
\text { provided }\end{array}$ & $\begin{array}{l}\text { Aboriginal Interpreter } \\
\text { Coordinator employed } \\
\text { by the hospital. } \\
\text { Also, Interpreters } \\
\text { employed by the NT } \\
\text { Aboriginal Interpreter } \\
\text { Service. }\end{array}$ & $\begin{array}{l}\text { Training was provided by staff from the } \\
\text { NT Aboriginal Interpreter Service, with } \\
\text { coordination provided by a clinical } \\
\text { champion and a Menzies School of } \\
\text { Health Research project officer. }\end{array}$ & $\begin{array}{l}\text { Champions were } \\
\text { volunteer } \\
\text { healthcare } \\
\text { providers employed } \\
\text { by the hospital. }\end{array}$ \\
\hline How & $\begin{array}{l}\text { The Aboriginal } \\
\text { Interpreter } \\
\text { Coordinator: } \\
\text { - Did ward rounds of } \\
\text { the hospital to } \\
\text { identify language } \\
\text { needs and coordinate } \\
\text { interpreter bookings } \\
\text { was an obvious } \\
\text { presence on wards. } \\
\text { - Provided in-services } \\
\text { on a regular basis to } \\
\text { healthcare providers } \\
\text { especially nurses and } \\
\text { allied health } \\
\text { practitioners, } \\
\text { promoting interpreter } \\
\text { use } \\
\text { - Provided mentoring } \\
\text { and support for onsite } \\
\text { interpreters, especially } \\
\text { the rostered } \\
\text { interpreter }\end{array}$ & $\begin{array}{l}\text { 'Working with Interpreter' training } \\
\text { sessions were provided at the hospital } \\
\text { in a meeting room easily accessible to } \\
\text { the target healthcare provider group } \\
\text { during lunch break or during a standing } \\
\text { timeslot for training. }\end{array}$ & $\begin{array}{l}\text { Clinical } \\
\text { championing of } \\
\text { interpreter use was } \\
\text { embedded into } \\
\text { practice by } \\
\text { champions pro- } \\
\text { actively identifying } \\
\text { language needs } \\
\text { and booking } \\
\text { interpreters where } \\
\text { needed for } \\
\text { Aboriginal patients } \\
\text { under their care, } \\
\text { and promoting } \\
\text { interpreter use in } \\
\text { informal } \\
\text { discussions with } \\
\text { colleagues. } \\
\text { Regular meetings } \\
\text { with Aboriginal } \\
\text { Interpreter } \\
\text { Coordinator, } \\
\text { researchers and } \\
\text { clinical champions } \\
\text { were held to } \\
\text { troubleshoot } \\
\text { barriers to using } \\
\text { interpreters. }\end{array}$ \\
\hline
\end{tabular}




\begin{tabular}{|c|c|c|c|}
\hline Item & \multicolumn{3}{|l|}{ Description } \\
\hline Where & \multicolumn{3}{|c|}{$\begin{array}{l}\text { Royal Darwin Hospital, Northern Territory, Australia. This is a } 360 \text {-bed public tertiary } \\
\text { referral hospital and the largest hospital in the Northern Territory. }\end{array}$} \\
\hline When & $\begin{array}{l}\text { April 2018-March } \\
2019\end{array}$ & $\begin{array}{l}\text { One-off training sessions were held on } \\
\text { September } 2018 \text {, October 2018, } \\
\text { January } 2019\end{array}$ & $\begin{array}{l}\text { April 2018-March } \\
2019\end{array}$ \\
\hline $\begin{array}{l}\text { How } \\
\text { much }\end{array}$ & $\begin{array}{l}\text { One full time } \\
\text { Aboriginal Interpreter } \\
\text { Coordinator role was } \\
\text { filled for the } 12 \text {-month } \\
\text { intervention period }\end{array}$ & $\begin{array}{l}\text { The three training sessions were } \\
\text { attended by } 83 \text { healthcare providers ( } 82 \\
\text { doctors and } 1 \text { nurse). }\end{array}$ & $\begin{array}{l}\text { The clinical } \\
\text { champions } \\
\text { participated for the } \\
\text { 12-month } \\
\text { intervention period. }\end{array}$ \\
\hline Tailoring & \multicolumn{3}{|c|}{ Not applicable (one participating site only) } \\
\hline \multirow[t]{4}{*}{$\begin{array}{l}\text { Modifi- } \\
\text { cations }\end{array}$} & $\begin{array}{l}\text { Roles of the } \\
\text { Aboriginal Interpreter } \\
\text { Coordinator evolved } \\
\text { and ultimately } \\
\text { focused chiefly on: }\end{array}$ & No modifications from original plan & $\begin{array}{l}\text { No modifications } \\
\text { from original plan }\end{array}$ \\
\hline & $\begin{array}{l}\text { - Advocacy: } \\
\text { Advocating for the } \\
\text { cultural and language } \\
\text { needs of patients to } \\
\text { improve } \\
\text { communication and } \\
\text { achieve culture } \\
\text { change. }\end{array}$ & & \\
\hline & $\begin{array}{l}\text { - Mentoring and } \\
\text { support for } \\
\text { interpreters when on } \\
\text { site: ensuring that } \\
\text { interpreters, especially } \\
\text { new staff, can be } \\
\text { supported to feel } \\
\text { confident in the } \\
\text { challenging and } \\
\text { potentially alienating } \\
\text { healthcare } \\
\text { environment. }\end{array}$ & & \\
\hline & $\begin{array}{l}\text { - Education for } \\
\text { healthcare providers: } \\
\text { on when and how to } \\
\text { use an Aboriginal } \\
\text { interpreter. }\end{array}$ & & \\
\hline
\end{tabular}




\begin{tabular}{|c|c|c|c|}
\hline Item & Description & & \\
\hline $\begin{array}{l}\text { How well } \\
\text { (reach) }\end{array}$ & $\begin{array}{l}\text { The Aboriginal } \\
\text { Interpreter } \\
\text { Coordinator was } \\
\text { active across all } \\
\text { wards of the hospital. } \\
\text { On the basis of the } \\
\text { summary above, } \\
\text { reach was judged as } \\
\text { being good. }\end{array}$ & $\begin{array}{l}\text { While the training was well received and } \\
\text { of importance to ensure that healthcare } \\
\text { provider expectations of and } \\
\text { interactions with Aboriginal interpreters } \\
\text { are appropriate, only a small proportion } \\
\text { of total healthcare providers attended } \\
\text { the working with interpreter training } \\
\text { sessions. Reach was therefore judged } \\
\text { as being limited. }\end{array}$ & $\begin{array}{l}\text { Clinical } \\
\text { championing } \\
\text { provides a } \\
\text { sustainable, no- } \\
\text { cost strategy for } \\
\text { modelling } \\
\text { behaviour } \\
\text { associated with } \\
\text { improving quality } \\
\text { of care. However as } \\
\text { only three clinical } \\
\text { champions were } \\
\text { involved in the } \\
\text { study and had } \\
\text { junior roles in the } \\
\text { medical hierarchy, } \\
\text { reach was judged } \\
\text { to be limited. }\end{array}$ \\
\hline
\end{tabular}

'Working with Interpreter' training was provided for emergency and surgical division doctors in September and October 2018, and for all new interns during orientation in January 2019 shortly before the intervention phase of the study ended. While the sessions were well-received (unpublished), no 'spikes' or uptrends in Aboriginal interpreter use was seen following these sessions[13]. Rather the increase in interpreter uptake (and decrease in self-discharge rate) coincided with commencement of the Aboriginal Interpreter Coordinator and continued to steadily improve thereafter.

Clinical championing of interpreter use comprised hospital junior medical officers who ensured appropriate use of interpreters in their clinical practice and advocated use to colleagues. In addition to these volunteers, a number of hospital clinicians across levels of seniority have been longstanding champions for interpreter use and cultural safety. For this study, champions met regularly with the study team to discuss ways to promote Aboriginal interpreter use. This component was incorporated since championing by peers or organisational leaders is considered an important strategy to achieve sustainable clinician behaviour change [22]. However the champions in this study were not in leadership positions. As junior medical officers, they rotated through different rosters including night shifts. They had power to change their own practice and potentially influence colleagues, but since only three champions were engaged, their ability to impact a large health service was considered to be relatively low (Table 2).

\section{Other activities during 2016-2019}

Independent from this study, an initiative in the hospital cardiac care unit from January 2018 comprised production and distribution of Aboriginal language lanyard cards matching community names with languages to help determine what language the patient might speak, and providing a guide to booking an interpreter including phone and email contacts[23]. This initiative might have contributed to improved 
interpreter uptake. It commenced during the study baseline period but may have gained momentum during the intervention phase.

Other initiatives aiming to decrease self-discharge and improve cultural safety had been occurring, guided by TEHS' Organisational Culture Charter, the Northern Territory Aboriginal Cultural Security Framework[24] and the Australian National Safety and Quality Health Service Standards[25]. The hospital foyer was renovated to position the Aboriginal Support Unit at the entrance, display Aboriginal artworks and acknowledge traditional owners (works completed December 2017). Additionally, in 2016 self-discharge data were included as a key indicator in monthly performance reports to motivate reductions in selfdischarge rates. These activities may be contributing to growing momentum in provision of more culturally safe care (including increased interpreter use for Aboriginal language speakers) that improves patient experience and thereby decreases self-discharge. However, the activities pre-dated the study intervention period and therefore are unlikely to have had a large role in contributing to the specific changes shown in the interrupted time-series analysis.

\section{Relationship between self discharge and interpreter bookings}

During the whole 3-year study period (baseline and intervention phases), a statistically significant inverse association occurred between interpreter bookings and likelihood of self-discharge among Aboriginal inpatients (Fig. 1); regression coefficient - 55.2 (95\% Cl -99.5 to -10.9).

\section{Discussion}

During a hospital-based multi-component intervention to improve Aboriginal interpreter uptake, a significant increase in the proportion of Aboriginal patients gaining access to an interpreter occurred, and self-discharge rates among Aboriginal people fell. In this analysis, we have determined that employment of an Aboriginal Interpreter Coordinator was likely the most important activity contributing to these findings, given the change in intercept in the time-series analysis noted on commencement of the role, and lack of noticeable 'spikes' coinciding with the timing of the 'Working with Interpreter' training sessions. The impact of the three junior clinical champions we considered likely to be smaller. However, in teasing apart the potential components, we acknowledge that there may have been synergism from the 'bundled' interventions; multi-component strategies are acknowledged as being potentially more successful in changing health systems and clinician behaviour than single-strategy approaches[11, 26].

Previous research has identified that interventions seeking to 'restructure and reinforce new practice norms and associate them with peer and reference group behaviours' may be successful in achieving behaviour change [26]. In this study, the activities were intended to make it easier for clinicians to recognise the need for Aboriginal interpreters, book an interpreter, and interact with the interpreter and patient more effectively - and to 'normalise' this behaviour. Approaching this through training and championing, as well as providing the mechanism to enable new behaviours (through a Coordinator) led 
to success in achieving the study's goals of increased interpreter uptake and improved patient outcome, measured as a decrease in self-discharge.

The association between interpreter bookings and self-discharge rates was explored in more detail. The logic is that better-informed patients who have access to an interpreter have better comprehension of the need to receive hospital care, and better experience of care, leading to a lesser likelihood of selfdischarge. Not only did interpreter uptake and self-discharge show significant changes in gradient during the 12-month study implementation phase compared with the baseline period as already described[12]; these outcomes also showed a linear (inverse) relationship with each other throughout the 3-year baseline and intervention period (Fig. 1). This provides internal validity in attributing the fall in selfdischarge rates to the rise in interpreter bookings. This is to our knowledge the first time this association has been shown, and corroborates previous suggestions of a likely association between better communication and lower self-discharge rates [8-10]. While this lends weight to there being a causal relationship between these measures, data linked by patient identifier would provide much stronger evidence for a direct association between access to an interpreter and reduction in self-discharge; this needs to be explored in future research.

Non-study activities may have contributed to the changes seen. The hospital has been striving to decrease self-discharge, currently targeting 7\% (3\% lower than was attained by the end of this study). New measures to improve cultural safety for Aboriginal people have been implemented. However, the study intervention dates showed a particular association with the change in outcomes.

A limitation of this study is the difficultly genuinely measuring 'reach' of each intervention component. Qualitative data exploring why clinicians do or don't use interpreters may have helped determine the relative importance of different study components. Related in-depth qualitative work is underway focusing on remaining barriers [27] and further system-strengthening activities are planned to scale up these study findings and to implement the Australian National Standards on Quality and Safety in Health care, which include 'communicating for safety' [25]. We have used TIDieR as an evaluation tool whereas it was developed as a descriptive tool for intervention components [14]. We suggest it has a useful role in this regard due to the clarity and simplicity of the structure. We also recognise that the success attributed to an Aboriginal Interpreter Coordinator role may have depended to a large extent on the particular skillset of that individual, who was confident in engaging with clinicians and other relevant personnel. Replicating success in the future may require careful selection in appointing to such a role.

\section{Conclusions}

Use of interpreters for people who primarily speak an Aboriginal language is one critically important component of culturally safe communication in healthcare. Improvements in interpreter uptake, with associated change in health behaviours and outcomes, can be achieved through systems changes incorporating Aboriginal leadership. Further strategies to escalate the proportion of Aboriginal patients getting access to high-quality communication in this setting are required to improve health outcomes. To 
achieve the much greater-magnitude change now required, substantial investment in combined strategies for upscaling Aboriginal interpreter use addressing supply, demand, efficiency and effectiveness, are needed.

\section{Declarations}

\section{Ethics approval and consent to participate}

Approval was provided by the Ethics Committee of the Northern Territory Department of Health and Menzies School of Health Research (HREC-2017-3007 and HREC-2018-3245). Individual participants were not recruited and consent to participate was not required.

\section{Consent for publication:}

NA

\section{Availability of data and material:}

Available on request

Competing interests:

None

\section{Funding}

This study was supported by the Menzies School of Health Research Grants Scheme, and Improving Health Outcomes in the Tropical North: A Multidisciplinary Collaboration (HOT NORTH), National Health and Medical Research Council GNT1131932. APR is supported by a National Health and Medical Research Council fellowship (1142011).

\section{Authors' contributions}

APR designed and led the study and developed the first manuscript draft; VK implemented the study and contributed to data interpretation; CC was the Aboriginal Interpreter Coordinator who implemented study activities; VM was the project officer who coordinated the study including data access and cleaning; EOC, $\mathrm{MH}$ and NK were clinical champions who helped to implement the study, collect data and contribute to data interpretation; RA supervised working with interpreter training and provided a liaison role between researchers and the health service; GM supervised the Aboriginal Interpreter Coordinator and contributed to study implementation; $C R$ runs the interpreter service and helped implement interpreter provision; $A C$ co-designed the study and provided academic leadership. 


\section{Acknowledgements}

We greatly thank the Aboriginal Interpreter Service and Top End Health Services for provision of data. We also thank Dr Zhiqiang Wang for statistical analysis of the original study, and Associate Professor Bhavini Patel for supporting the study.

\section{References}

1. Flores $\mathrm{G}$. The impact of medical interpreter services on the quality of health care: a systematic review. Med Care Res Rev. 2005;62:255-99.

2. Karliner LS, Jacobs EA, Chen AH, Mutha S. Do professional interpreters improve clinical care for patients with limited English proficiency? A systematic review of the literature. Health Serv Res. 2007;42:727-54.

3. Northern Territory Government. (2020) Aboriginal languages in NT. Aboriginal Interpreter Service, Interpreting and Translating Services.

4. Ralph AP, Lowell A, Murphy J, Dias T, Butler D, et al. Low uptake of Aboriginal interpreters in healthcare: exploration of current use in Australia's Northern Territory. BMC Health Serv Res. 2017;17:733.

5. Coroners Court Alice Springs (29. October 2010) Inquest into the death of Kristelle Ruby Mulladad aka Oliver. Findings of Mr Greg Cavanagh SM. https://www.nt.gov.au/_data/assets/pdf_file/0008/208781/a00572008-kristelle-oliver.pdf.

6. Australian Broadcasting Corporation. (20 July 2019) Low use of Indigenous interpreters at Royal Darwin Hospital putting patients at risk, researchers say. ABC News.

7. Allam L. (21 September 2018) Darwin hospital left Aboriginal man to die alone and in agony from surgical injury. Northern Territory coroner issues scathing report detailing multiple failures by Top End Health Service. The Guardian.

8. Einsiedel LJ, van lersel E, Macnamara R, Spelman T, Heffernan M, et al. Self-discharge by adult Aboriginal patients at Alice Springs Hospital, Central Australia: insights from a prospective cohort study. Aust Health Rev. 2013;37:239-45.

9. Australian Institute of Health and Welfare. (2017) Aboriginal and Torres Strait Islander Health Performance Framework report, Northern Territory https://www.aihw.gov.au/reports/indigenoushealth-welfare/health-performance-framework/contents/overview.

10. Henry B, Dunbar T, Barclay L, Thompson R. (2007) Self-discharge against medical advice from Northern Territory Hospitals: Prevalence rates, experiences and suggestions, economic implications and recommended strategies for improvement. A Report Prepared for the Department of Health and Community Services. Charles Darwin University and Co-operative Research Centre for Aboriginal Health. 
11. Lavallee JF, Gray TA, Dumville J, Russell W, Cullum N. The effects of care bundles on patient outcomes: a systematic review and meta-analysis. Implement Sci. 2017;12:142.

12. Communicate Study Group. (2020) Improving communication with Aboriginal hospital inpatients: a quasi-experimental interventional study. Med J Aust.

13. Craig P, Dieppe P, Macintyre S, Michie S, Nazareth I, et al. Developing and evaluating complex interventions: the new Medical Research Council guidance. BMJ. 2008;337:a1655.

14. Hoffmann TC, Glasziou PP, Boutron I, Milne R, Perera R, et al. Better reporting of interventions: template for intervention description and replication (TIDieR) checklist and guide. BMJ. 2014;348:g1687.

15. Jandoc R, Burden AM, Mamdani M, Levesque LE, Cadarette SM. Interrupted time series analysis in drug utilization research is increasing: systematic review and recommendations. J Clin Epidemiol. 2015;68:950-6.

16. Curtis $\mathrm{E}$, Jones $\mathrm{R}$, Tipene-Leach $\mathrm{D}$, Walker $\mathrm{C}$, Loring $\mathrm{B}$, et al. Why cultural safety rather than cultural competency is required to achieve health equity: a literature review and recommended definition. Int J Equity Health. 2019;18:174.

17. National Collaborating Centre for Indigenous Health C. (2013) Towards Cultural Safety for Métis: An Introduction for Heath Care Providers. In: Columbia CUoNB, editor.

18. Australian Institute of Health and Welfare. Australian Institute of Health and Welfare 2019. Cultural safety in health care for Indigenous Australians: monitoring framework. Cat. no. IHW 222. Canberra: AlHW; 2019.

19. Australian Bureau of Statistics. (2018) Main language spoken at home and English proficiency 2018. 2076.0 - Census of Population and Housing: Characteristics of Aboriginal and Torres Strait Islander Australians.

20. Kerrigan V, McGrath SY, Lee B, Puruntatameri P, Herdman RM. Communicating with interpreters and your patient. In: Kerrigan V, editor. Ask the Specialist: Larrakia, Tiwi and Yolnu stories to inspire better healthcare. Australia: Darwin; 2020.

21. (2017) Stata Software, StataCorp. Stata Statistical Software: Release 15. College Station, TX: StataCorp LLC.

22. Australian Commission on Safety and Quality in Health Care National Safety and Quality Health Service Standards Guide for Hospitals Australian Commission on Safety and Quality in Health Care. (2017) National Safety and Quality Health Service Standards Guide for Hospitals. https://www.safetyandquality.gov.au/sites/default/files/migrated/National-Safety-and-QualityHealth-Service-Standards-Guide-for-Hospitals.pdf. Sydney, Australia.

23. Williams J. (2019) Improving Aboriginal and Torres Strait Islander Patient Care: Royal Darwin Hospital - Coronary Care Unit. Reducing Discharge Against Medical Advice. Lighthouse Hospital Project National Forum. 30 April - 2 May 2019. Melbourne: National Heart Foundation of Australia. https://www.lighthouseproject.com.au/. 
24. Northern Territory Health. (2016) Aboriginal Cultural Security Framework 2016-2026.

25. Australian Commission on Safety and Quality in Health Care. (2017) National Safety and Quality Health Service Standards. 2nd ed. Sydney.

26. Johnson MJ, May CR. Promoting professional behaviour change in healthcare: what interventions work, and why? A theory-led overview of systematic reviews. BMJ Open. 2015;5:e008592.

27. Mithen V, Dhurrkay G, Morgan T, Castillon C, Kerrigan V, et al. (2020) Aboriginal patient and interpreter perspectives on the delivery of culturally safe hospital-based care. Health Promotion Journal of Australia submitted.

\section{Figures}

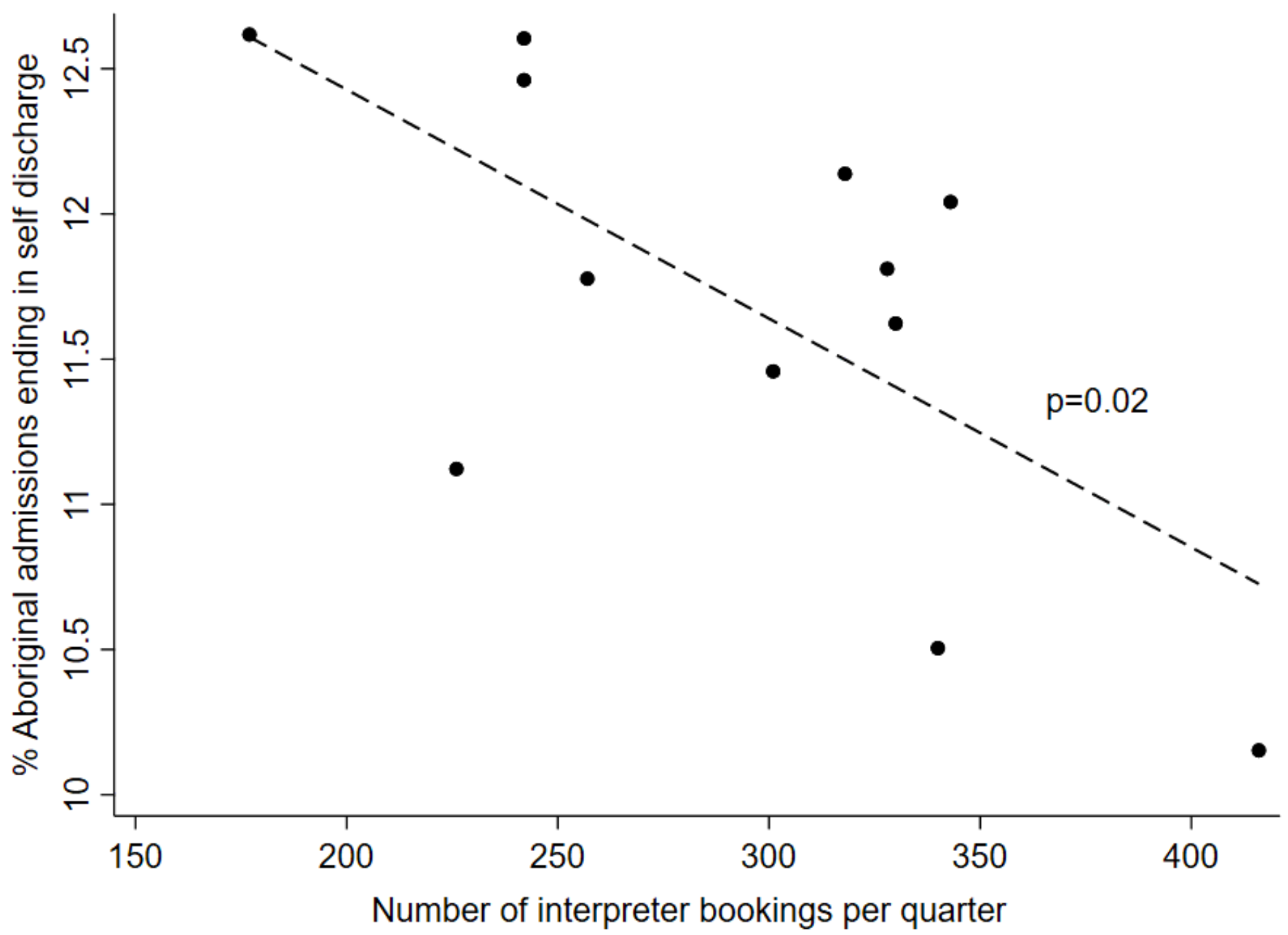

Figure 1

Self discharge rates among Aboriginal inpatients according to number of interpreter bookings made per quarter during baseline and study intervention period (April 2016 to March 2019) Legend: dashed line shows line of best fit. $\mathrm{P}$ value derived from linear regression analysis. 